\title{
Garnet growth in frictional melts of the Ivrea Zone (Italy)
}

\author{
Lidia Pittarello $(*),(* *)$, Gerlinde Habler $(*)$, Rainer Abart $(*)$ \& Dieter Rhede $(* * *)$
}

\section{ABSTRACT}

Pseudotachylytes, coseismic frictional melts, have formed in metagabbro and within a kinzigitic shear zone of the Ivrea Zone (Italy). In both rock types, amoeboid garnet has crystallized in the pseudotachylyte matrix, locally as a rim overgrown on pre-existing garnet clasts. This new garnet has been previously used to constrain the frictional melt formation in such rocks by applying geothermobarometric calculations. Here we present a complete microstructural textural and compositional characterization, by high-resolution scanning electron microscopy, focused ion beam tomography, electron backscatter diffraction and electron microprobe analysis. The garnet in pseudotachylyte exhibits subtle major element compositional and microstructural differences between the core and the overgrown rim. This suggests that the new garnet formed by rapid epitactic overgrowth on clasts of relic host rock garnet, during frictional melt cooling and solidification.

KEY WORDS: Crystal growth, garnet, pseudotachylyte.

\section{INTRODUCTION}

Pseudotachylytes, solidified frictional melts formed within seismic faults in silicate rocks (SIBSON, 1975), outcrop now on the Earth's surface due to tectonic exhumation, providing information from the seismogenic depth. Nevertheless, evidence of the ambient conditions prevailing during the coseismic frictional slip may have been obliterated during subsequent deformation and/or recrystallization. In some cases, pseudotachylyte formation under high temperature conditions is indicated by coeval ultramylonite formation, indicative of high-temperature deformation (PASSCHIER, 1982; HoBBS et alii, 1986; CAMACHO et alii, 1995; PENNACCHIONI \& CESARE, 1997, etc.). Although the origin of these high temperature pseudotachylytes is still a matter of discussion (e.g., WHITE, 2012, and reference therein), the crystallization of high temperature phases may retain information on the thermal evolution of the frictional melt and, therefore, constrain the ambient condition of the seismic shear slip.

In the pseudotachylytes of Premosello, Ivrea Zone, Italy, new garnet grains were observed along margins of frictional melt veins formed in garnet-bearing metagabbro and in a thick mylonitic band with felsic composition, adjacent to the metagabbro (PITTARELlo et alii, 2012). The authors have used garnet and orthopyroxene pairs in

(*) Department of Lithospheric Research, University of Vienna, Althanstrasse, 14 - 1090 Vienna, Austria.

(**) Present address: Earth System Science, Vrije Universiteit Brussel, Pleinlaan, 2 - 1050 Elsene, Brussels, Belgium (lidia.pittarello@ vub.ac.be), Tel. +32-2-629-1418

(***) Helmholtzzentrum Potsdam, Deutsches Geoforschungszentrum, Telegrafenberg - 14473 Potsdam, Germany. the pseudotachylyte formed in the metagabbro for geothermometry calculations, yielding a temperature range of $570-620^{\circ} \mathrm{C}$, depending on the confining pressure $(0.4-1.0 \mathrm{GPa})$ that could not be estimated. This estimate is consistent with those from associated ultramylonites (calculation based on plagioclase-amphibole couples, yielding a temperature of $500-650^{\circ} \mathrm{C}$ ) and has been therefore considered a constraint for the pseudotachylyte formation in amphibolite facies conditions. Austrheim et alii (1996) observed that garnet in a pseudotachylyte in the Bergen Arcs, Western Norway was intensively fractured and preferentially molten. The melting of garnet has been explained by its sensitivity to mechanical comminution under specific conditions, although garnet is generally considered a refractory phase. These authors also observed the crystallization of new small grains of hypidiomorphic or dendritic garnet with a slightly higher $\mathrm{Fe} / \mathrm{Mg}$ ratio than the garnet in the host rock. The formation of these new grains was ascribed to the following eclogitization. Also LUND \& AUSTRHEIM (2003) have reported the occurrence of similar new garnet, with an amoeboid shape that the authors compared to that of a cauliflower, rimming pyroxene clasts in pseudotachylyte formed in eclogite facies rocks within the Western Gneiss Region, Norway. Other dendritic garnet grains growing in pseudotachylytes, which formed under high-grade metamorphic conditions, were described by MOECHER \& STELTENPOHL (2009) and used to estimate re-equilibration conditions. Recently ALTENBERGER et alii (2011 and 2013) reported the occurrence of garnet grains, crystallized from a frictional melt, in the Calabrian Serre Massif, Southern Italy.

Here we present a detailed microstructural, textural and geochemical investigation of the garnet grains, found in close relation with Premosello pseudotachylytes. The characterization of garnet in pseudotachylyte is followed by a discussion on the possible formation processes in the framework of the frictional melt evolution. The occurrences in the metagabbro and in the kinzigitic shear zone will be treated in separate sections and shortened as metagabbro- and felsic-pseudotachylytes. The acronyms pt-Grt and hr-Grt will be used for garnet in the pseudotachylyte and in the host rock respectively. Mineral abbreviations follow WHITNEY \& EvANS (2010): orthopyroxene $(\mathrm{Opx})$, garnet (Grt), plagioclase (Pl), ilmenite (Ilm), magnetite (Mag), almandine (Alm), pyrope (Prp), grossular (Grs), andradite (Adr), and spessartine (Sps).

\section{GEOLOGICAL SETTING AND SAMPLE DESCRIPTION}

Pseudotachylytes have formed under amphibolitefacies metamorphic conditions in metagabbro and in a 


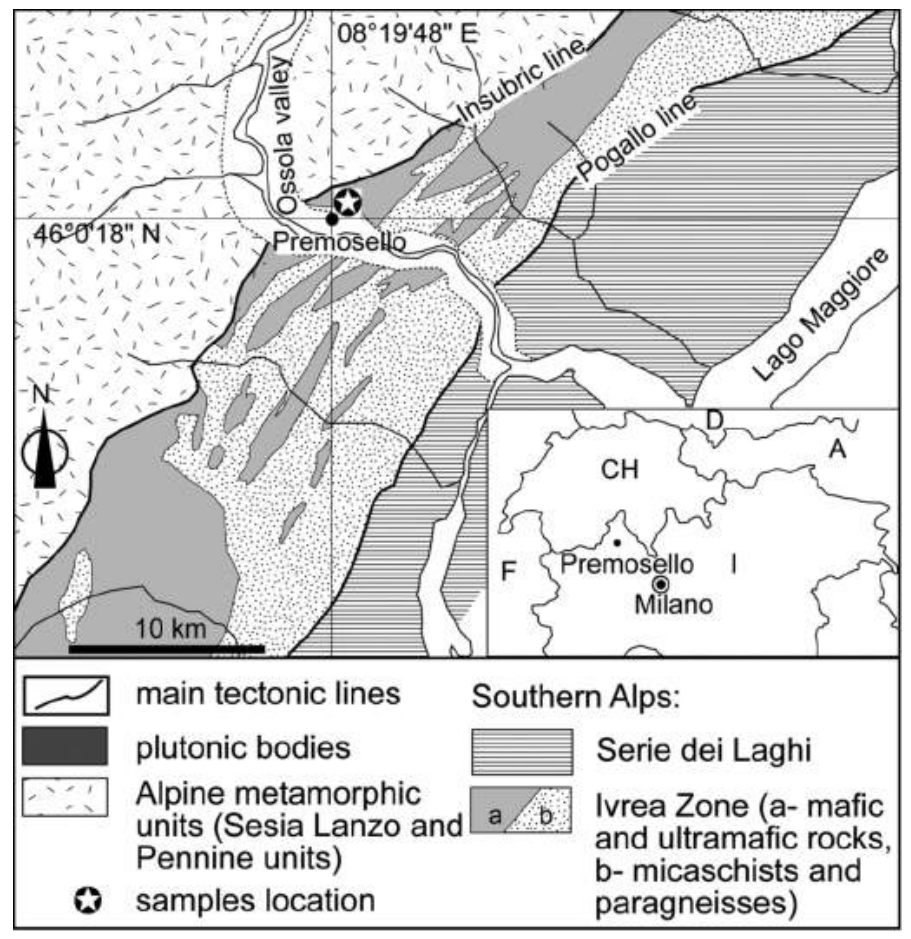

Fig. 1 - Geological setting of the Premosello area within the Ivrea Zone (modified after HANDY et alii, 1999). The geographic location is shown in the inset.
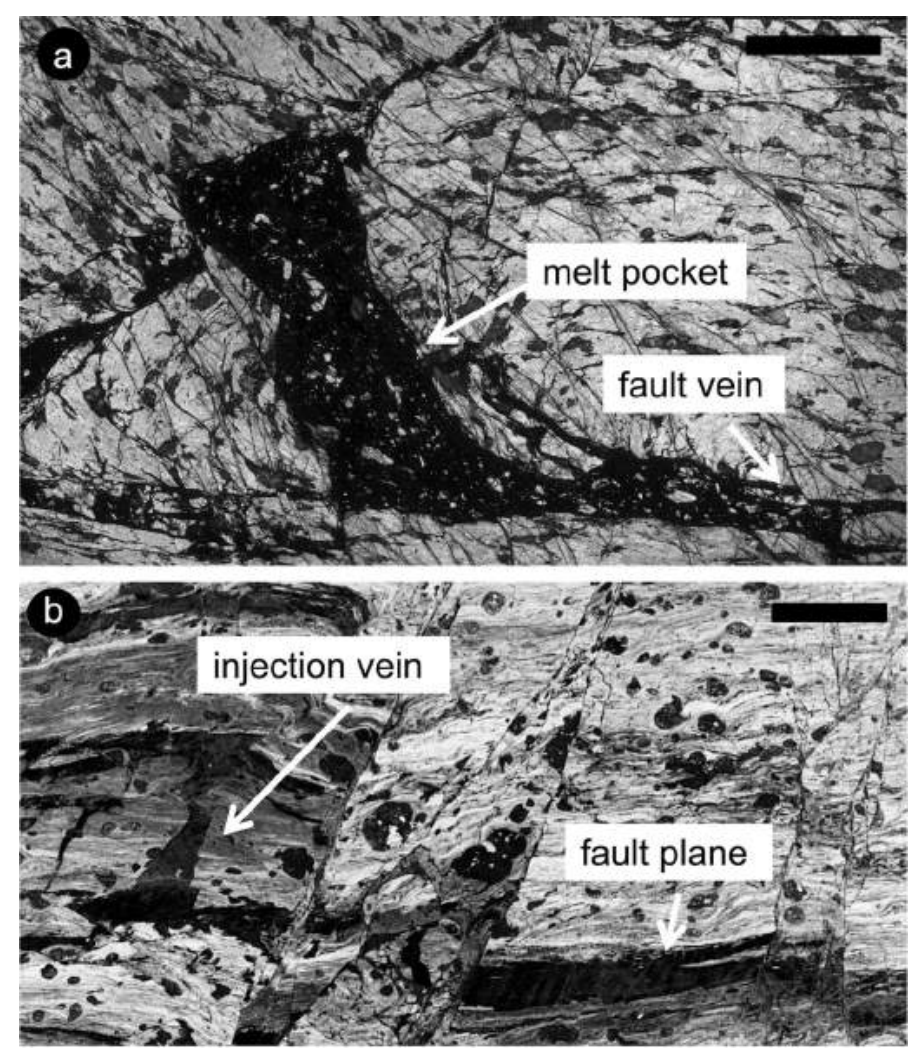

Fig. 2 - Premosello pseudotachylytes in thin section (plane-polarized light images): $a$ ) Melt pocket in the metagabbro departing from the fault vein; $b$ ) Mutual overprinting relationship between the pseudotachylyte and the felsic mylonite. The black bar indicates $5 \mathrm{~mm}$ in both images.

mylonitic band of felsic composition of the Premosello area, Ossola Valley, Italy, in units belonging to the Ivrea Zone (fig. 1) (PitTAREllo et alii, 2012). The Ivrea Zone represents a slice of pre-Alpine continental lower crust and sub-continental mantle tectonically exhumed and now exposed in the Italian Southern Alps (ZINGG et alii, 1990; Demarchi et alii, 1998; WolfF et alii, 2012). The metagabbro in the Premosello area consists of plagioclase, garnet, amphibole and pyroxene, and might belong to the bodies emplaced by magmatic underplating or sub-horizontal intrusion at the base of the continental crust $299 \pm 5$ Ma before present (DEMARCHI et alii, 1998; VAVRA et alii, 1999; SINIGOI et alii, 2011) or even earlier, during preliminary stages of the extensional regime, at ca. 314 Ma (e.g., EwING et alii, 2013; KLÖTZLI et alii, 2014). The metagabbro was subsequently highly deformed at granulite facies conditions forming localized shear zones (280-270 Ma). These are characterized by the breakdown of pyroxene and garnet and the formation of fine-grained orthopyroxene, anorthite, and oxide symplectites (BRODIE \& RUTTER, 1985; HANDY et alii, 1999). Mylonitization occurred during a cooling stage at amphibolite facies conditions $\left(650-500^{\circ} \mathrm{C}\right.$; HANDY, 1987; BORIANI et alii, 1990). Mylonitization with similar features and under similar metamorphic conditions was described in the Finero area, referring the formation of high strain shear zones to the activity of the Pogallo line, at 230-180 Ma (KenkMANn \& DRESEN, 2002). The pseudotachylytes within the metagabbro are 4-5 $\mathrm{mm}$ thin blackish layers (fig. 2a), consisting of a fine-grained granoblastic matrix of orthopyroxene $\left(\mathrm{En}_{63}\right)$, plagioclase $\left(\mathrm{An}_{54}\right)$ and $\mathrm{Fe}-\mathrm{Ti}$ oxides (magnetite and ilmenite), and a few relict, subrounded clasts of plagioclase that survived melting. Relic flow fabric and plagioclase microlites have been observed along injection veins oriented normal to the main veins. Microstructural observations and geothermometry suggest that the pseudotachylytes and ultramylonites in the Premosello metagabbro formed coevally under amphibolite facies conditions (PITTARELLO et alii, 2012).

The felsic mylonite in the Premosello area belongs to a $10 \mathrm{~m}$-thick shear zone that separates the metagabbro and the paragneiss units. The felsic mylonite consists of alternating leucocratic ribbons, which are composed of quartz, oligoclase and K-feldspar, with less than $5 \mathrm{~m}$ in grain size, and dark ribbons mainly composed of biotite. Embedded large (up to $5 \mathrm{~mm}$ in size) and extensively fractured garnet porphyroclasts are dragged in the mylonitic foliation and are partially replaced by finegrained aggregates of biotite, quartz, and K-feldspar. Less than $2 \mathrm{~mm}$ thick pseudotachylyte veins occur subparallel to the mylonitic foliation, with injection veins normal to the foliation and with their tips dragged into the foliation (fig. 2b). The pseudotachylyte consists of a fine-grained $(5-10 \mathrm{~m})$ aggregate of plagioclase, K-feldspar, quartz, biotite, ilmenite and rutile. The granoblastic fabric likely reflects recrystallization during ductile deformation, but locally pristine pseudotachylyte features are preserved, such as an increase in grain size from the margin to the centre of the vein (mimetic on the spherulitic and microlitic domains described in DI TORO \& Pennacchioni, 2004) and the occurrence of tiny spherical Fe- and Ti-oxides, which generally originate from immiscibility in a silicic melt (e.g., MAGLOUGHLIN, 1992). The mineral paragenesis and the mutual overprinting relationships between the mylonite and the pseudotachylyte suggest coeval formation under amphi- 
bolite facies conditions $\left(500-570^{\circ} \mathrm{C}\right.$ and $0.4-0.6 \mathrm{GPa}$; PitTAREllo et alii, 2012).

\section{METHODS}

The microstructures in the metagabbro and in the fault rocks were investigated in polished, 35 m-thick thin sections, which were prepared by mechanical and final chemo-mechanical polishing. The latter was performed on an active rotary-head polisher using a colloidal silica suspension with $\mathrm{pH}$ 9.2-10 (Köstrosol ${ }^{\mathrm{TM}}$ 3530). A FEI Inspect S50 scanning electron microscope (SEM), equipped with an EDAX Apollo XV silicon drift detector for EDX spectrometry was used for SE- and BSE imaging and qualitative major element compositional analysis at instrument settings of $10 \mathrm{~mm}$ working distance (WD) and 10-15 kV accelerating voltage. Focused ion beam (FIB) tomography and Electron Backscatter Diffraction analysis (EBSD) were performed using a FEI Quanta 3D FEG instrument at the Centre of Earth Sciences at the University of Vienna (Austria). This FIB-SEM is equipped with a field-emission electron source for electron microscopy at high spatial resolution and a field-emission Gallium source for nano-machining. Furthermore, an EDAX Digiview IV EBSD camera is attached allowing for crystallographic orientation mapping at high spatial resolution. EBSD data collection was performed at instrument settings of $13 \mathrm{~mm}$ $\mathrm{WD}, 70^{\circ}$ sample tilt, $15 \mathrm{kV}$ accelerating voltage and $2 \mathrm{nA}$ beam current in analytic mode using a SEM aperture of $1 \mathrm{~mm}$. The OIM Data Collection and Analysis software $\mathrm{v}$ 6.2. $\times$ has been used for EBSD data acquisition and processing. EBSD patterns were collected with a $4 \times 4$ binning of the Digiview IV camera, an exposure time of 90 milliseconds and applying several pattern image filters (Static Background Subtraction, Dynamic Background Subtraction, Intensity Histogram Normalization). Hough settings were at a Binned Pattern Size of 160 , a Theta step size of $1^{\circ}$, a Rho-fraction of $80 \%$ applying a $9 \times 9$ convolution mask. A maximum of $12-13$ and a minimum of 6 Hough peaks were used for indexing. Lattice orientations were mapped using beam scanning at a step size of $60-80 \mathrm{~nm}$. EBSD maps were re-indexed based on saved Hough peaks using reference structure files for garnet, plagioclase, rutile, magnetite, ilmenite and quartz.

Serial sections for FIB tomography were prepared by automated alternating FIB sputtering and BSE imaging using the FEI AutoSlice and View ${ }^{\mathrm{TM}}$ software. An ion beam accelerating voltage of $30 \mathrm{kV}$ and a beam current of $3 \mathrm{nA}$ were applied for the removal of $0.1 \mathrm{~m}$ thick slices. After each cut, an image was taken using the electron beam and a solid-state BSE detector. Before 3D reconstruction, the images were cut, the contrast enhanced and the brightness adjusted, the alignment corrected, and the series was converted into binary (black and white) stacks with the software ImageJ, Fiji, and MacBiophotonics. The 3-D visualization was elaborated with Amira and the 3-D tool of ImageJ.

Microprobe analyses, including high spatial resolution element maps and compositional profiles, were carried out on a JEOL thermal field-emission instrument JXA-8500F (HYPERPROBE) at the German Research
Centre for Geosciences (GFZ), Helmholtz Centre Potsdam (Germany). The point analyses were carried out with an acceleration voltage of $10 \mathrm{kV}$, a beam current of $20 \mathrm{nA}$, and a beam diameter of $1 \mathrm{~m}$. The following natural and synthetic standards were used (respective element and peak counting time listed in brackets): albite (for $\mathrm{Na} ; 20 \mathrm{~s}$ ), orthoclase (for Al; $20 \mathrm{~s}$ ), diopside (for Mg; $20 \mathrm{~s}$, Si; $20 \mathrm{~s}$, $\mathrm{Ca} ; 20 \mathrm{~s}$ ), hematite (for $\mathrm{Fe} ; 30 \mathrm{~s}$ ), rhodonite (for Mn; $30 \mathrm{~s}$ ), rutile (for $\mathrm{Ti} ; 30 \mathrm{~s}$ ) and $\mathrm{Cr}_{2} \mathrm{O}_{3}$ (for $\mathrm{Cr} ; 30 \mathrm{~s}$ ). The background counting times were always set to half of the respective peak counting times. The CITZAF routine in the JEOL software was used for data processing. High spatial resolution element maps were produced in WDS mode using an acceleration voltage of $10 \mathrm{kV}$, a beam current of $20 \mathrm{nA}$, and dwell times of $500 \mathrm{~ms}$ per pixel. We accumulated a $350 * 300$ pixel frame with a step size of $0.06 \mathrm{~m}$ and a $360 * 360$ pixel frame with a step size of $0.1 \mathrm{~m}$ in stage scanning mode.

\section{GARNET IN METAGABBRO-PSEUDOTACHYLYTES}

\section{OCCURRENCE AND MORPHOLOGY}

The pt-Grt mainly occurs in clusters along the pseudotachylyte margins (fig. 3a), but individual grains are also present. The grain size is generally $\sim 10 \mathrm{~m}$, with a few exceptions at smaller grain size $\left(\begin{array}{lll}\sim & \mathrm{m}\end{array}\right)$. The pt-Grt exhibits a sub-hypidiomorphic grain shape, having straight faces intersected by matrix minerals (orthopyroxene, plagioclase, and Fe- or Fe-Ti-oxides, about $2 \mathrm{~m}$ in size; fig. $3 a-b)$. Garnet grains along the vein margins commonly include a population of coarse-grained crystals of magnetite and ilmenite, which are larger than in the rest of the pseudotachylyte matrix (fig. 3a). These inclusions generally exhibit elongation parallel to the vein margin.

Some Grt grains exhibit an inclusion- and pore-free core, surrounded by a rim that has intergrowth with matrix minerals or contains abundant inclusions (fig. 3b-d). The Grt core generally has an angular shape (fig. 3b and c) but in some cases displays rounded margins and resorption embayments (fig. $3 \mathrm{~d}$ and e). When present, the garnet core is generally rimmed by a layer, which appears bright in the BSE image and has a thickness lower than $1 \mathrm{~m}$ (fig. 3b-e). This layer locally contains ultra finegrained ( $\sim 1-2 \mathrm{~m})$ inclusions of mainly magnetite and subordinately ilmenite. FIB serial sections of the Grt grains have revealed the 3-D geometry of the different domains of the pt-Grt and the distribution of inclusions and pores (fig. 3f). Mineral inclusions and subordinately pores are uniformly distributed in the garnet rim and control the complex shape of the garnet rim, which is connected to the garnet core through a few bridges over mineral inclusions.

Matrix phases are spatially closely related with the dendritic growth rim of the pt-Grt. Orthopyroxene (Opx) and plagioclase $(\mathrm{Pl})$ form amoeboid grains, which follow garnet faces, whereas magnetite and ilmenite usually have rounded shapes (e.g., fig. 3c and d). In contrast, in the matrix Opx and Pl form hypidiomorphic crystals (e.g., fig. 3b). The orthopyroxene in the pt-Grt has the same composition and grain size as the Opx in the pseudotachylyte matrix. Locally, Opx grains contain ultrafinegrained inclusions, which seem to be locally arranged 

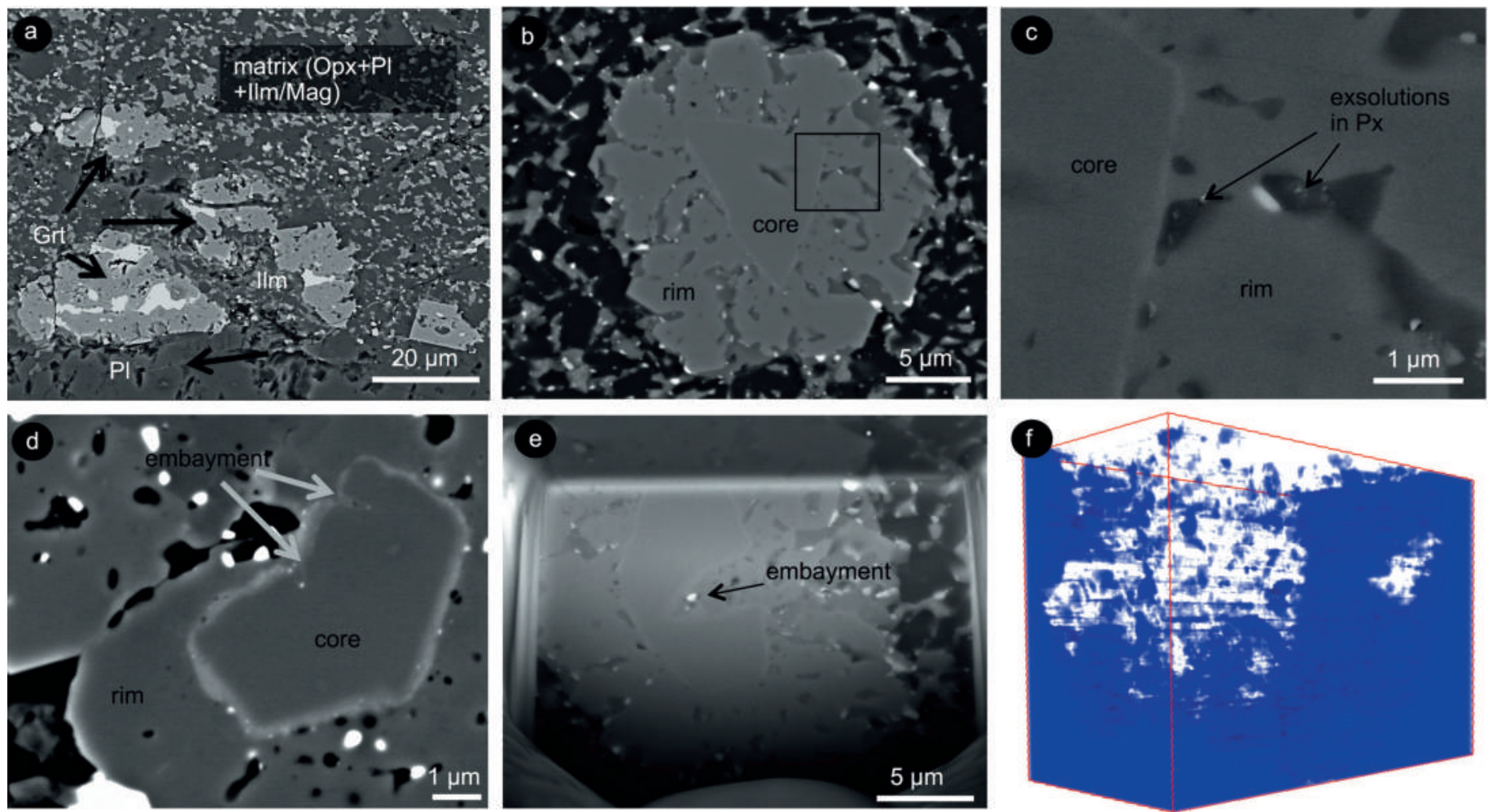

Fig. 3 - Garnet in metagabbro-pt: microstructures (BSE-SEM images): a) Occurrence of pt-Grt along the pseudotachylyte margin (Plg $=$ plagioclase Grt = garnet, Ilm = ilmenite, $\mathrm{Px}=$ pyroxene, $\mathrm{Ox}=\mathrm{Fe}$-oxide); $b$ ) A garnet grain showing a core-and-rim structure. Notice the angular shape of the core, marked by a thin bright layer between the rim and the core; $c$ ) A detail of the core-rim transition from (b). Notice the pyroxene inclusions in garnet (darker grey in the BSE image), with tiny exsolution of Fe-Ti oxides (very bright); $d$ ) Resorption embayment in garnet cores; $e$ ) BSE-SEM image of one single FIB slice, showing the complex shape of the garnet rim, the maximum thickness of the bright layer bounding the core and the large resorption embayment in the core itself. The rounded feature at the bottom of the image represents redeposited material produced by FIB milling; $f$ ) 3-D rendering of the Grt inclusions and porosity, which are concentrated in the rim.
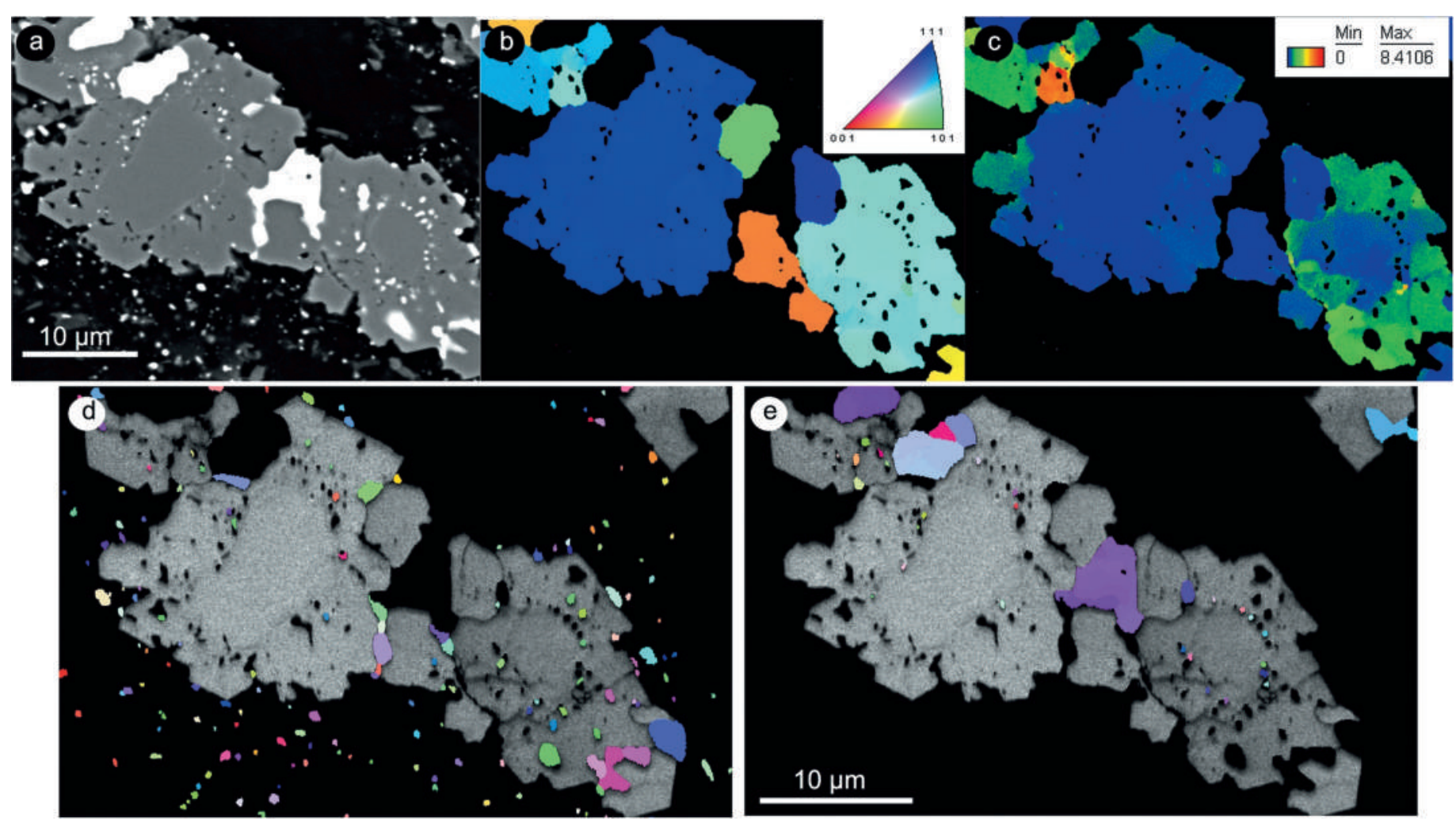

Fig. 4 - Garnet in metagabbro-pt: lattice orientation analyses: $a$ ) BSE-SEM image of the selected grains; $b$ ) EBSD inverse pole figure map of the same area, with Grt crystal directions relative to the sample normal; $c$ ) EBSD grain reference orientation deviation map, which displays the orientation deviation of each point with respect to the average orientation of the respective grain; $d$ ) EBSD inverse pole figure map of ilmenite, showing the distribution of ilmenite with respect to garnet displayed as pattern quality map in metagabbro-pt; $e$ ) The same for magnetite. 
along crystallographic planes of Opx (fig. 3c). The BSE signal intensity of these inclusions suggests the presence of Fe-oxides.

Magnetite and ilmenite in pt-Grt form two grainsize populations. A first population is represented by up to $5 \mathrm{~m}$ sized, irregularly distributed inclusions within and intergrowths with pt-Grt (fig. 4), and locally with a preferred shape orientation, as described above. A second population consists of ultra fine-grained $(<1 \mathrm{~m})$ crystals, which are arranged along the core-rim interface of the Grt or are enclosed by the pt-Grt rim. These inclusions could only be identified as ilmenite and magnetite by EBSD analysis (fig. $4 \mathrm{~d}$ and e). Chemical analysis was not possible due to the small grain-size. Although the investigated area is not representative of the whole pseudotachylyte vein, ilmenite seems to be evenly present in the pseudotachylyte matrix and in the pt-Grt area, as both distribution and average size, whereas magnetite seems to occur preferentially in the pt-Grt domains (fig. 4e).

\section{CRYSTALLOGRAPHIC ORIENTATION}

EBSD data were collected by mapping a $44 \times 31$ micrometre sized sample domain, with a step size of 80 $\mathrm{nm}$, in order to spatially resolve the inclusions and the boundary geometry between the core and the rim domains of the garnet (fig. 4). Due to the small step size and consequent pattern degradation (WISNIEWSKI et alii, 2011), the matrix phases Pl and Opx did not yield sufficient EBSD pattern quality for proper indexing. Cluster domains of garnet resulted consisting of individual grains, although this is not obvious from the microstructures (fig. 4b). In addition, EBSD data showed that garnet rim domains approximately have the same lattice orientation as the core, although minor intragranular orientation variations were observed in the garnet rim (fig. 4c). The grain reference orientation deviation map, which documents the misorientation of each point with respect to the average lattice orientation of the corresponding grain, shows that the garnet rim is characterized by small angular (up to $2-4^{\circ}$ ) misorientations of different rim domains (fig. 4c). In some clusters, the intragranular lattice orientation variations seem to progressively increase towards the garnet rim. Contrastingly, the garnet core domains display a uniform lattice orientation.

Considering the crystallographic orientation of magnetite and ilmenite inclusions, there was no unique crystallographic orientation relation observed between sub-micron scale inclusions and the host garnet grain although some coincidences of Grt (111) and Mag (110) planes occur.

\section{GEOCHEMISTRY}

PitTARello et alii (2012) observed a significant difference in composition between the hr-Grt $\left(\mathrm{Alm}_{47} \operatorname{Prp}_{34}\right.$ $\left.\operatorname{Grs}_{15} \operatorname{Adr}_{3} \mathrm{Sps}_{2}\right)$ and the pt-Grt $\left(\mathrm{Alm}_{64} \mathrm{Grs}_{12} \operatorname{Prp}_{11} \mathrm{Adr}_{8}\right.$ $\mathrm{Sps}_{5}$ ). The largest differences are shown by the $\mathrm{Mg} / \mathrm{Fe}$ ratio, which is much lower in the pt-Grt. New microprobe analyses confirm this trend between the pt- and hr-Grt, although the difference in composition between the core and rim of the pt-Grt is less obvious. The chemical differences between Grt core and rim are illustrated in the ternary diagrams in fig. 5. Comparison of the new analyses of the pt-Grt with the previous data from the hr-Grt confirms the behaviour described in PitTARELlo et alii (2012). The pt-Grt is enriched in Fe, and to a minor extent in $\mathrm{Mn}$, and it is depleted in $\mathrm{Mg}$ with respect to the hr-Grt. The dendritic garnet overgrowth that form the rim is further slightly enriched in Fe and Mn with respect to the core, which in some cases has compositions close to that of the hr-Grt. In other cases, the cores have a composition almost indistinguishable from that of the rim. Only one analysis of the bright layer between the rim and the core shows a clear enrichment in $\mathrm{Ti}$.

Element distribution mapping was performed for selected elements in a pt-Grt showing a well developed rim structure (fig. 5). Aluminum and titanium are enriched in the bright layer between the core and rim and generally along the margins of the new grain. Calcium, iron and magnesium exhibit negligible variations between the core and the rim, except a local enrichment of $\mathrm{Ca}$ within the bright layer along the core-rim interface. Manganese seems to concentrate to form separate garnet grains, but generally is slightly more abundant at the very external part of the rim, as expected in retrograde metamorphic reaction (e.g., SPEAR, 1993). The magnetite and ilmenite inclusions in garnet are readily identified from the high concentrations of $\mathrm{Fe}$ and $\mathrm{Ti}$, respectively.

\section{GARNET GRAINS IN FELSIC-PSEUDOTACHYLYTES}

\section{OCCURRENCE AND MORPHOLOGY}

The pseudotachylyte in felsic mylonite is marked by a continuous layer of fine-grained Grt grains along the pseudotachylyte margins. This garnet layer seems to be connected to coarse garnet porphyroclasts in the host mylonite (fig. 6a). In the injection veins, the pt-Grt grains follow the cuspate interface between the melt vein and the host mylonite (fig. 2b). The thickness of this pt-Grt layer is about $50 \mathrm{~m}$ and the size of each aggregate ranges from 10 to $50 \mathrm{~m}$. The layer consists of aggregates of fine-grained garnet grains with amoeboid shape (fig. 6b). Among the pt-Grt, clasts of the hr-Grt locally occur, which are surrounded by pt-Grt aggregates (fig. 6c). The hr-Grt clasts display angular shape with micron-scale cuspate boundary segments, resembling resorption embayments. However, also in pt-Grt of the felsic mylonites, hr-Grt clasts with an overgrown rim were observed, generally localized in the vicinity of a large hr-Grt in the wall rock.

The pt-Grt aggregates enclose phases of the pt-matrix (fig. 6d), such as quartz, plagioclase and ilmenite, but also some pores. These pores locally contain tiny spherules of ilmenite and rutile (fig. 6d). Unfortunately, the size of such pores has prevented possible fluid inclusion analysis. The 3-D reconstruction documents the amoeboid shape of the pt-Grt aggregates (fig. 6e and f), where individual grains are connected by thin bridges of Grt, whose thickness seems to decrease and finally disappear in the outermost grains.

\section{CRYSTALLOGRAPHIC ORIENTATION}

EBSD data were obtained from two microstructurally different garnet domains, a large garnet aggregate 

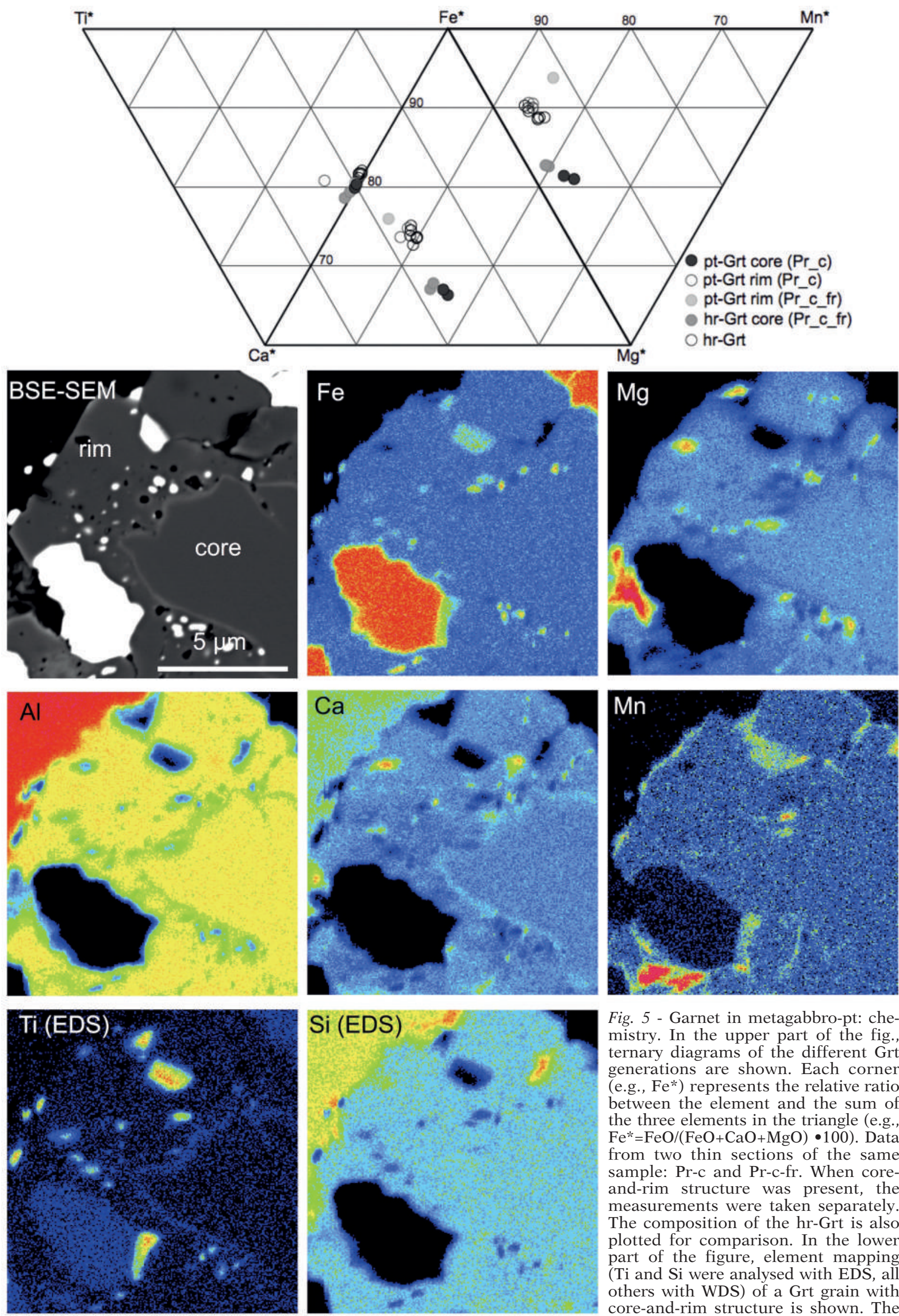

Fig. 5 - Garnet in metagabbro-pt: chemistry. In the upper part of the fig. ternary diagrams of the different Grt generations are shown. Each corner (e.g., $\mathrm{Fe}^{*}$ ) represents the relative ratio between the element and the sum of the three elements in the triangle (e.g., $\left.\mathrm{Fe}^{*}=\mathrm{FeO} /(\mathrm{FeO}+\mathrm{CaO}+\mathrm{MgO}) \bullet 100\right)$. Data from two thin sections of the same sample: Pr-c and Pr-c-fr. When coreand-rim structure was present, the measurements were taken separately. The composition of the hr-Grt is also plotted for comparison. In the lower part of the figure, element mapping ( $\mathrm{Ti}$ and $\mathrm{Si}$ were analysed with EDS, all others with WDS) of a Grt grain with first image represents a BSE image of the investigated area, whereas the other images are qualitative intensity maps of individual elements. The compositional difference between the core and the rim is negligible in this grain, except for local anomalous concentration of $\mathrm{Mn}$ and the bright layer between core and rim that is clearly marked by higher content of $\mathrm{Ca}$ and $\mathrm{Ti}$ with respect to the rest of the garnet. 

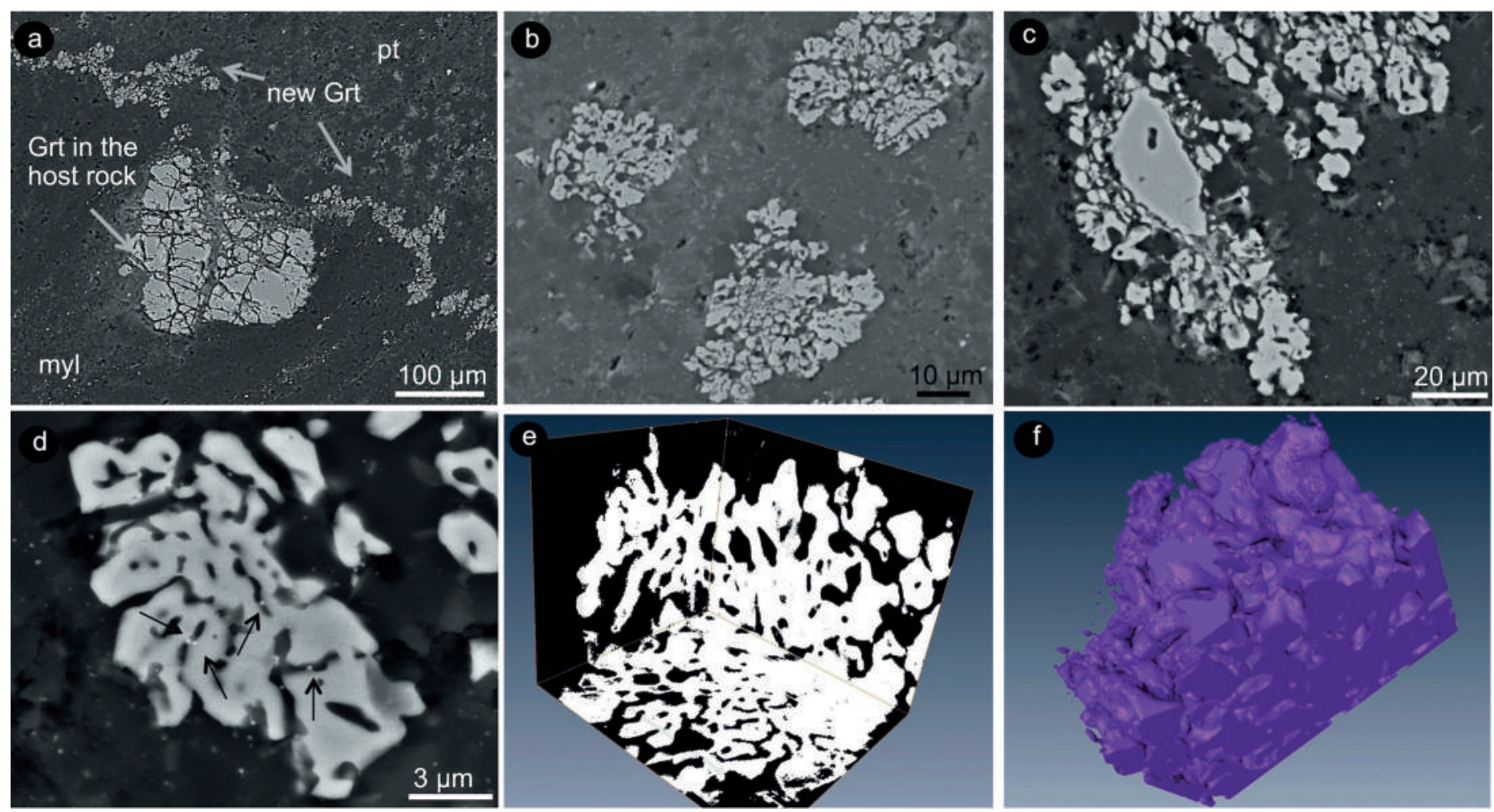

Fig. 6 - Garnet in felsic mylonite-pseudotachylytes: microstructures: a) Occurrence of the new garnet grains (new Grt) at the margin of the pseudotachylyte (pt), close to a garnet grain in the wall rock. Notice that the foliation in the mylonite (myl) is normal to the pseudotachylyte injection vein; $b$ ) New garnet grains forming amoeboid aggregates; $c$ ) Clast of hr-Grt surrounded by aggregates of new garnet grains; $d$ ) Detail of a new garnet grain that reveals a complex microstructure, including matrix phases and tiny bright inclusions of possibly Fe- and Ti-oxides (marked with arrows). BSE-SEM images; $e$ ) Orthogonal projection of a pt-Grt aggregate, as obtained by FIB slicing; $f$ ) 3-D reconstruction of the same aggregate. Notice the complex growth shape.

(fig. 7a-d) and a cluster of pt-Grt locally showing a porefree core and an overgrown rim (fig. $7 \mathrm{e}-\mathrm{i}$ ), $44 \times 45 \mathrm{~m}$ and a $21 \times 26$ m sized area respectively, both mapped at a step size of $60 \mathrm{~nm}$. The first investigated domain has no recognizable core and consists of subdomains with differing lattice orientations (fig. 7b-d). These subdomains have an angular misorientation of $15-30^{\circ}$ with respect to each other and an additional smaller orientation variations within each subdomain (fig. 7b). Despite of the polycrystalline nature of the garnet aggregate, the pole figure plot suggests, that there was at least a common origin for some of the different aggregate subdomains (fig. 7c and d). The second investigated domain includes several aggregates, one of them comprising a core domain (fig. 7e-i). EBSD data from Grt that has an inclusion- and pore-free core shows that the core has a uniform lattice orientation (fig. 7f), whereas each individual of the inclusion-rich rim domain apparently shows a progressive misorientation with respect to the inclusion-free core towards the rim (fig. $7 \mathrm{f}$ and g). These individual aggregates do not have any mutual crystallographic orientation relation in the pt-Grt cluster (fig. 7h and i).

\section{GEOCHEMISTRY}

Slight compositional variations were observed between hr-Grt, hr-Grt clasts in the pseudotachylyte matrix and pt-Grt (tab. 1). According to PitTARELlo et alii (2012), the composition of the pt-Grt in the felsic pseudotachylytes is slightly enriched in almandine-component with respect to the porphyroclasts of hr-Grt, which has a higher $\mathrm{Mg} / \mathrm{Fe}$ ratio. The composition of different grains belonging to the pt-Grt aggregates, which were newly analysed with the microprobe for this work, plots in the same area in fig. 8. As expected, the clasts of hr-Grt (labelled "pt-Grt core") in the pseudotachylyte have a composition enriched in $\mathrm{Mg}$ with respect to the pt-Grt, but appear to be also slightly depleted in Mg with respect to the hr-Grt. The hr-Grt and the clasts apparently have a slightly higher content of $\mathrm{Ca}$ than the pt-Grt, which, on the contrary, have slightly higher content of $\mathrm{Mn}$. The variations in $\mathrm{Ti}$ content are negligible. In a pt-Grt with a core-and-rim structure, identifiable by differing inclusion-densities, these compositional features are enhanced (tab. 1). The dendritic garnet forming the rim exhibits subordinate major element compositional variations, as shown in the ternary diagrams in fig. 8 . The content of $\mathrm{Fe}$ and $\mathrm{Mg}$ in the rim is less uniform than in the core and shows opposite trends. Similar to the garnet in the metagabbro pseudotachylyte, the rim of Grt in felsic pt shows a steep increase in Ti. In addition, the Grt-core is enriched in Ca whereas the rim is slightly enriched in Mn.

A pt-Grt aggregate was chosen for producing an element distribution map (fig. 8). There are no major compositional variations throughout the aggregate, but Fe seems to be slightly enriched along the rim of the individual grains and $\mathrm{Ca}$ seems to be enriched in the central domains of the grains. In addition, the grains at the bottom left of the image seem to be slightly enriched in $\mathrm{Mn}$ and $\mathrm{Fe}$ with respect to the rest of the Grt aggregate. 


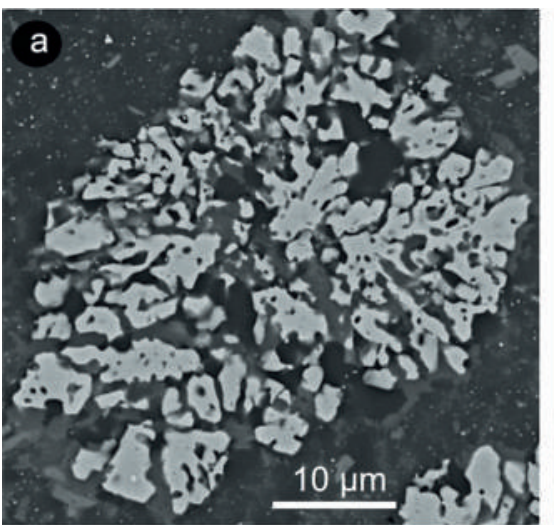

d
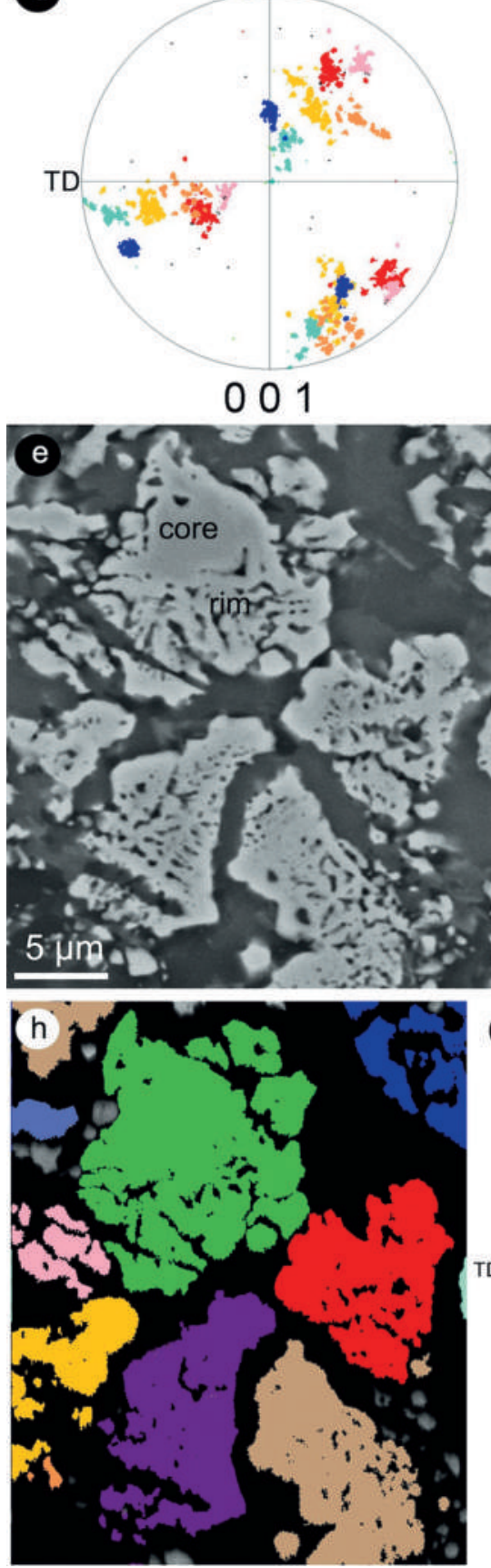
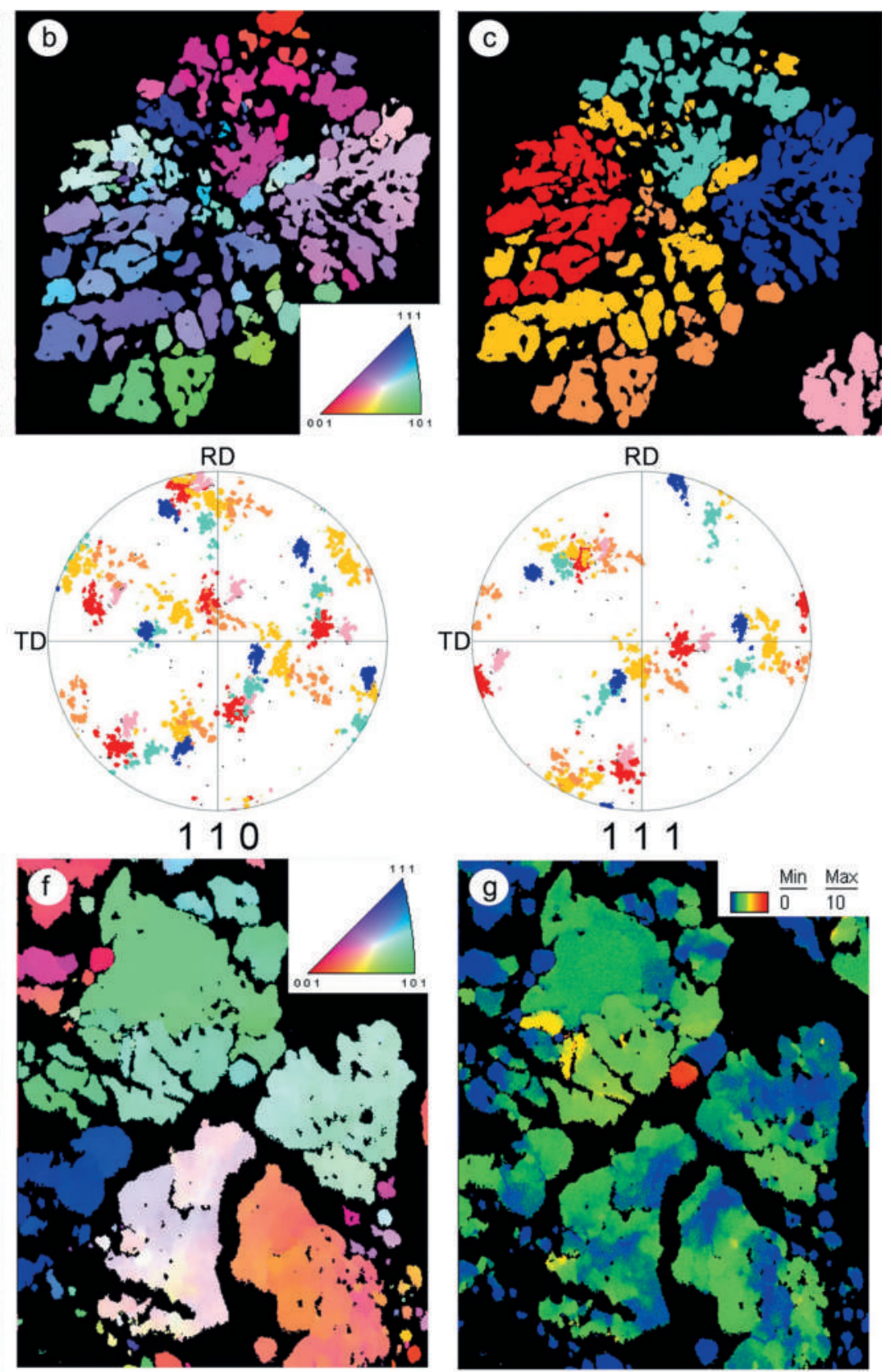

$$
111
$$

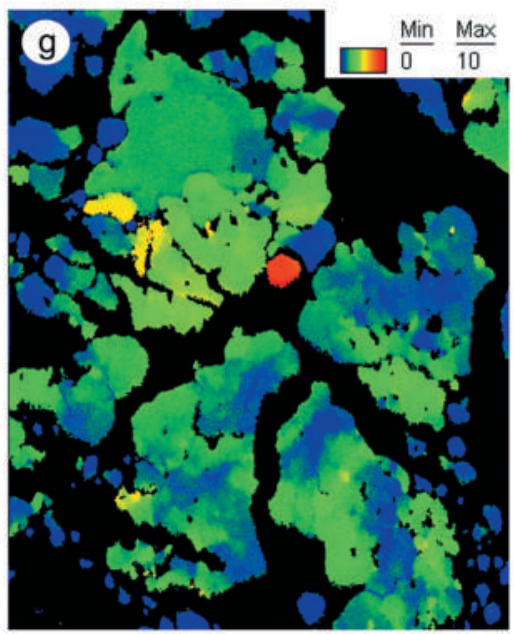

(i)
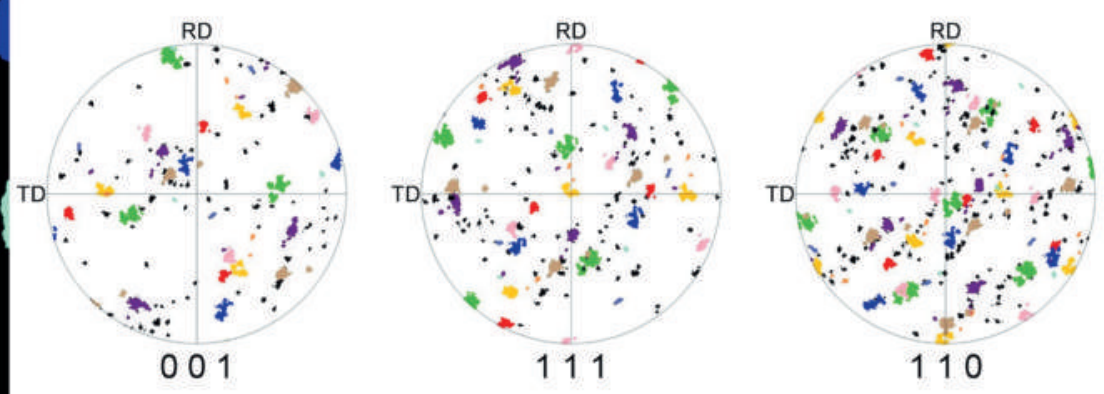

Fig. 7 - Garnet in felsic myl-pt: lattice orientation analyses. SEM images ( $a$ and $e$ ), inverse pole figures $(b$ and $f)$, grain reference orientation deviation map $(g)$, and pole figures $(d$ and $i)$ of an aggregate of pt-Grt apparently without core domain $(a-d)$ and of some grains with apparent core-and-rim structure $(e-i)$. Explanation in the text. 


\section{DISCUSSION}

\section{GARNET OCCURRENCE AND MORPHOLOGY}

The garnet modal content in the pseudotachylyte is negligible compared with the host rock, whereas plagioclase and, in minor amount, pyroxene clasts are common in the melt. Despite of the high melting temperature of garnet (generally above $1300^{\circ} \mathrm{C}$ ), garnet has been reported to melt preferentially in pseudotachylytes. AUSTRHEIM et alii (1996) ascribed this process to the intense comminution/fragmentation that affects the garnet in the early stage of faulting. In the Premosello rocks, garnet occurs locally in the pseudotachylytes in the form of new grains and rarely as clasts.

The pt-Grt grains preferentially occur along the pseudotachylyte margin and in many cases close to a fractured garnet in the wall rock. This is more obvious for the pseudotachylyte in the felsic ultramylonites, where hr-Grt is crosscut by pseudotachylytic veins and finegrained garnet grains are spread along the pseudotachylyte margin. On the contrary, very few Grt grains were observed in the centre of the melt vein in the metagabbros and no pt-Grt occurs in the central domain of the melt veins in both rock types. The pt-Grt is therefore concentrated at the pt-margins, where we assume that the melt temperature was slightly lower and where cooling lasted shorter, because of the smaller temperature difference between the melt and the host rock, than in the central portions of the pseudotachylyte veins, where the maximum melt temperature was reached (NIELSEN et alii, 2008). This might explain the preservation of garnet clasts along the melt vein margin. The lack of pt-Grt in the centre of the melt vein suggests that garnet melting proceeded to completion in this portion of the vein because of the higher temperature. In addition, the absence of clasts that serve as nuclei for new garnet growth has likely prevented the crystallization of new garnet in the central domain of the pseudotachylyte. In the metagabbro-pt, where the melt temperature was high enough to melt almost completely all the phases present in the metagabbro, melting of garnet clasts was probably the reason for the lack of new garnet grains at the centre of the vein. In the felsic-pt, the pt-Grt occurrence is correlated to large garnet crystals in the wall rock. In this case, the presence of pt-Grt along the vein margin is probably due to spreading of garnet fragments during the fault slip. There is no evidence of melting of garnet in the felsic-pt. In any case, the dendritic grain shape of the new garnet, the enrichment in inclusions (pointing to fast growth), and the occurrence of garnet clasts in the cores of the pt-Grt with evidence of magmatic resorption indicate local condition for fast garnet growth over a nucleation site, which is likely represented by a survived hr-Grt clast.

Interestingly, the microstructural asymmetry in the pseudotachylyte veins is not reflected by chemistry, as a chemical transect through the vein does not show any variation in the local bulk major element content. Except for a negligible amount of $\mathrm{Mn}$, the pt-Grt in gabbro-pt contains the same elements and in similar relative abundances as in the bulk pt-matrix, which consists of an aggregate of plagioclase, pyroxene and $\mathrm{Fe}$ - $\mathrm{Ti}$ - bearing oxides where crystallized. Thus, the concentration of garnet at the margin of the pt-veins does not reflect chemical segregation across the pt-vein but is rather due to the
TABLE 1

Microprobe analyses of garnet in felsic myl-pt. Analyses of pt-Grt only include new garnet grains aggregates.

\begin{tabular}{l|r|r|r|r}
\hline & $\begin{array}{c}\text { hr-Grt } \\
(\# 7)\end{array}$ & $\begin{array}{r}\text { pt-Grt } \\
(\# 20)\end{array}$ & $\begin{array}{r}\text { core } \\
(\# 8)\end{array}$ & \multicolumn{1}{c}{$\begin{array}{c}\text { rim } \\
(\# 3)\end{array}$} \\
\hline $\mathrm{wt}^{2}$ & & & & \\
$\mathrm{SiO}_{2}$ & 39.75 & 38.12 & 38.32 & 39.51 \\
$\mathrm{TiO}_{2}$ & 0.03 & 0.03 & 0.09 & 0.47 \\
$\mathrm{Al}_{2} \mathrm{O}_{3}$ & 22.43 & 20.85 & 22.07 & 20.06 \\
$\mathrm{Cr}_{2} \mathrm{O}_{3}$ & 0.12 & 0.04 & 0.08 & 0.05 \\
$\mathrm{FeO}$ & 28.46 & 37.44 & 30.32 & 34.93 \\
$\mathrm{MnO}$ & 0.59 & 2.05 & 0.88 & 1.23 \\
$\mathrm{MgO}$ & 10.65 & 2.39 & 8.07 & 4.24 \\
$\mathrm{CaO}$ & 1.64 & 1.07 & 2.10 & 0.95 \\
$\mathrm{Na}$ & 0.01 & 0.06 & 0.05 & 0.04 \\
\hline Total & 103.68 & 102.06 & 101.96 & 101.46 \\
\hline
\end{tabular}

local preservation or the coincidental presence of clasts derived from the pre-existing hr-Grt that enhanced nucleation on these Grt fragments.

\section{MiNERAL INCLUSIONS AND PORES IN PT-GRT}

As described above, the new pt-Grt contains abundant mineral inclusions and pores or shows intimate intergrowth with pt-matrix minerals. We interpreted this feature as evidence of fast growth. The mineral inclusions may represent relic, pre-existing overgrown matrix minerals, or alternatively they may have formed by precipitation within the garnet during re-equilibration. In both scenarios, their occurrence supports the hypothesis of fast growth of garnet, possibly followed by high grade, metamorphic conditions, corresponding to the ambient conditions.

Chemical components, such as $\mathrm{Ti}^{4+}$, may have been incorporated into the garnet during fast growth in proportions that cause a deviation from garnet stoichiometry. During prolonged annealing at metamorphic conditions, these components have been likely exsolved, forming precipitates. This mechanism might explain the occurrence of the ultra-fine grained ilmenite grains found along the core-rim boundary in the pt-Grt in meta-gabbro (figs. 3-5). The preferential occurrence of relatively large grains of magnetite in domains where pt-Grt occurs also suggests a correlation between magnetite crystallization and pt-Grt formation, as magnetite in the pt-matrix is rare. In fact, exsolution of magnetite from almandine garnet has been described in literature as a result of cooling below $550^{\circ} \mathrm{C}$ (BREARLEY \& CHAMPNESS, 1986). Although the estimated ambient temperature for Premosello pseudotachylyte in metagabbro is slightly higher $\left(570-620^{\circ} \mathrm{C}\right.$; PitTAREllo et alii, 2012), a similar phenomenon may have occurred, leading to $\mathrm{Fe}^{3+}$ exsolution from pt-Grt to form magnetite. The ambient high temperature might have favoured coarsening of the magnetite grains. These high temperature conditions do not seem to have affected minerals in the wall rock, suggesting that the heat source was the melt vein itself. Therefore, initial fast cooling has led to quenching of garnet with alien elements and has been likely followed by slow cooling, which allowed the exsolution of these elements. 

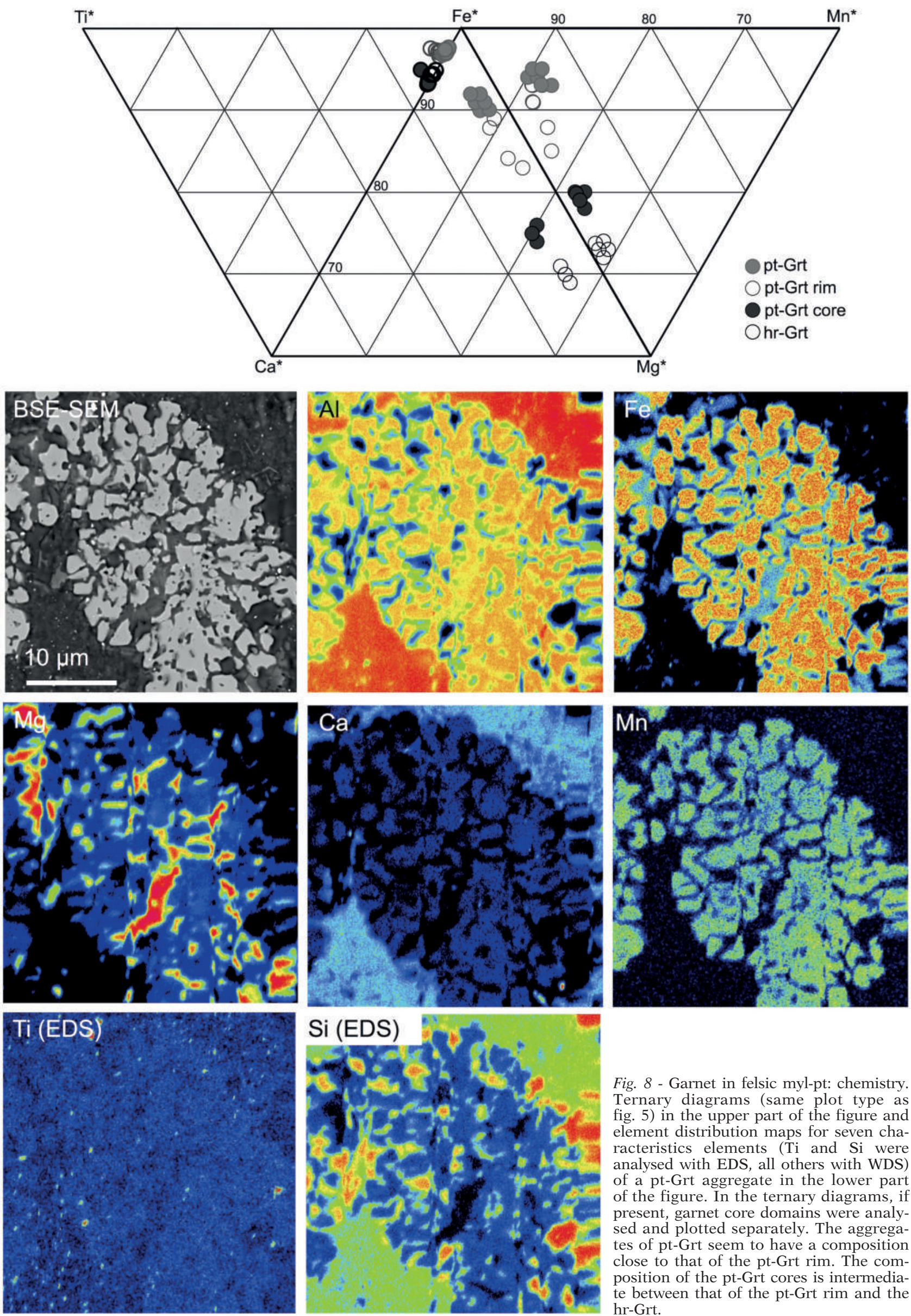

Fig. 8 - Garnet in felsic myl-pt: chemistry. Ternary diagrams (same plot type as fig. 5) in the upper part of the figure and element distribution maps for seven characteristics elements ( $\mathrm{Ti}$ and $\mathrm{Si}$ were analysed with EDS, all others with WDS) of a pt-Grt aggregate in the lower part of the figure. In the ternary diagrams, if present, garnet core domains were analysed and plotted separately. The aggregates of pt-Grt seem to have a composition close to that of the pt-Grt rim. The composition of the pt-Grt cores is intermediate between that of the pt-Grt rim and the hr-Grt. 
The grain size and the composition of plagioclase and orthopyroxene in close relation with the pt-Grt are comparable with those of these phases in the pt matrix. This suggests that presumably Grt, Pl, and Opx were in equilibrium and, therefore, their close association is the consequence of intergrowth. Nevertheless, the occurrence of ultrafine-grained inclusions in orthopyroxene, likely formed by exsolution, might indicate that pyroxene did not crystallize under complete equilibrium in the first place.

The pt-Grt in the felsic pseudotachylytes reflects a similar situation. The tiny spherical ilmenite grains in the pores in the pt-Grt (fig. 6d) likely resulted from exsolution, whereas the close association of Grt, quartz, $\mathrm{K}$-feldspar, and other phases of the pt-matrix is probably due to intergrowth.

\section{CRYSTALLOGRAPHIC ORIENTATION}

The lattice orientation of the newly formed garnet rim is clearly controlled by that of the preserved core, when present. This suggests epitaxial Grt-growth on fragments of pre-existing garnet.

In domains where relic hr-Grt-clasts are present as cores in pt-Grt aggregates, the intragranular angular misorientation seems to increase towards the rim of pt-Grt in both metagabbro- and felsic mylonite-pt. Contrasting with the homogeneous lattice orientation of the relic core, the dendritic pt-Grt rim consists of subdomains with slightly (up to $5^{\circ}$ ) differing lattice orientation. These may be a consequence of the dendritic growth and the abundance of matrix phases intergrown with the newly crystallized pt-Grt. There is no systematic Grt lattice rotation during progressive growth, which points to a growth feature rather than to an influence of externally imposed stress causing the crystallographic orientation variations.

In cases where relic core domains are apparently absent, as confirmed by 3-D slicing, the pt-Grt aggregates consist of several individual grains with differing crystallographic orientation. These grains may have originated from single or multiple nucleation sites. When formed from a single nucleus, distinct garnet aggregate domains show a common origin with only some angular misorientations of $15-30^{\circ}$ between adjacent subdomains (e.g., in felsic-pt; fig. 7b-d). When formed by coalescence during growth from multiple nuclei, the different subdomains lack any mutual crystallographic orientation relation (fig. 4b and d; fig. 7f, h and i), suggesting random crystallographic orientation also of the relic garnet clasts in the pseudotachylyte, consistently with the cataclastic behaviour of the hr-Grt. This seems to indicate also that the pt-Grt has crystallized during the cooling of the melt vein, after the slip has stopped, otherwise garnet grains would have shown at least a shape preferred orientation according to the flow direction.

\section{GARNET COMPOSITION}

The pt-Grt has generally lower $\mathrm{Mg} / \mathrm{Fe}$ than the hr-Grt. A similar trend is observed between the rim and the core of the pt-Grt, with the latter having a composition close to that of the hr-Grt. A more subtle composition trend is observed for $\mathrm{Ca}$ and $\mathrm{Mn}$, which are both relatively depleted in the newly formed garnet rims compared to the fragments of pre-existing garnet forming the cores of
pt-Grt. The systematic composition difference between pre-existing and newly formed garnet may be related to the crystallization temperature: the garnet in the metagabbro formed under granulite facies conditions $\left(800-900^{\circ} \mathrm{C}\right.$ and 1-1.2 GPa; HANDY et alii, 1999; EWING et alii, 2013) that implies higher $\mathrm{Mg}$ content in the almandine-pyrope garnet, whereas the garnet in the pseudotachylyte formed under lower temperature conditions, corresponding to amphibolite facies $\left(570-620^{\circ} \mathrm{C}\right.$ for $0.4-1.0 \mathrm{GPa}$ pressure range; PITTARELlo et alii, 2012) and therefore consistent with a lower $\mathrm{Mg}$ content and a higher Fe content in the garnet (e.g., RÅHEIM \& GREEN, 1974). However, the chemical variations described here are not recorded in all the pt-Grt grains, but rather the core domains and the rim have similar composition in some grains (fig. 5).

At high temperatures the compositional differences between the pt-Grt and the hr-Grt, as well as between the overgrown rim and the core of the pt-Grt, should have rapidly decreased due to intracrystalline diffusion (GAIDIES et alii, 2008; CADDICK et alii, 2010). Preservation of sharp composition gradients across the interface between garnet cores and the overgrowth indicates that cooling to the ambient temperature of amphibolite facies metamorphism was fast enough to prevent chemical equilibration between the core and the rim of pt-Grt. On the other hand, the prolonged annealing of the pt-assemblage at amphibolite facies metamorphic conditions, which followed the melt quench, supposedly lead to local equilibrium between the newly formed garnet and the orthopyroxene in immediate contact, as suggested by the lack of small scale composition zoning at their interfaces. Depending on the size of the preserved hr-Grt clast and on the local temperature in the pseudotachylyte vein (higher in the central part than along the margin), these chemical differences could be quenched and therefore preserved or completely obliterated by re-equilibration.

The difference in $\mathrm{Mg}$ and Fe content between the rim and the core domains in pt-Grt in gabbro-pt potentially provide information on the duration of the high temperature conditions (amphibolite facies) during the postseismic stage, based on the diffusion rate of such elements in garnet. The maximum distance between the core and the rim of such crystals is $\sim 5 \mathrm{~m}$. According to the experimental work by CARLSON (2006), in the case of the lowermost temperature in the experiments $\left(580^{\circ} \mathrm{C}\right)$, the diffusion rate of $\mathrm{Fe}, \mathrm{Mg}, \mathrm{Mn}$, and $\mathrm{Ca}$ is of the same order of magnitude. Applying very rough calculation, these coefficients will lead to 4-5 hours for a complete diffusion of the listed elements. The melt was likely at much higher temperature $\left(>1000^{\circ} \mathrm{C}\right)$ and diffusion was therefore faster, further reducing this short time to minutes. This implies that the melt cooling was almost instantaneous (otherwise the difference in composition between the core domains and the rim of pt-Grt would have been completely obliterated) and that the amphibolite conditions lasted long enough to allow a complete equilibration between the pt-Grt and the adjacent orthopyroxene.

\section{PSEUDOTACHYLYTE GARNET AS INDICATOR OF PT FORMATION CONDITIONS}

The newly formed garnet overgrowth has been used to provide constraints for the conditions of pseudotachylyte formation. A pseudotachylyte is a frictional melt that is first overheated during the formation and then 
quenched to the temperature of the host rock (SIBSON, 1975; Di Toro \& Pennacchioni, 2004; NiElsen et alii, 2008). As the pt-Grt shows evidence of overgrowth from a melt, determining the exact conditions of the garnet growth is, therefore, of key importance to characterize the ambient conditions during or immediately after the pseudotachylyte formation, assuming that the rock did not experience high grade metamorphism after the pseudotachylyte solidification, which would have overprinted the pseudotachylyte internal features. Nevertheless, the amphibolite facies condition in the host rock lasted long enough to cause the complete recrystallization of the pseudotachylyte matrix in the fault veins. The preferred occurrence of pt-Grt along the pseudotachylyte margins and the lack of garnet in the interior portions of the pt veins suggest syn- to post slip formation of the garnet overgrowth in a highly dynamic environment, where substantial temperature gradients existed between the central regions of the pseudotachylyte veins and the surrounding host rock. The dendritic shape of the garnet overgrowth, its close association with pt-matrix minerals and the preservation of the chemical differences between the core-and-rim domains of the pt-Grt are indicative of fast garnet growth.

The rapid garnet growth probably occurred far from equilibrium conditions, but when the temperature of the pseudotachylytes successively approached the ambient temperatures, cooling slowed down and prolonged annealing at metamorphic conditions led to the establishment of local equilibrium. The achievement of a local equilibrium is suggested by the small grain-size of the newly formed mineral phases (never larger than $10 \mathrm{~m}$, such as in the pt-matrix). This situation was not perturbed by possible events of prograde metamorphism, which would have been recorded in the garnet. Therefore, the use of a geothermometer based on garnet-pyroxene pairs (after GANGULY \& SAXENA, 1984; for details see PitTAREllo et alii, 2012) for the gabbro-pt is legitimated by the possible garnet history constrained in this work. Obviously, only orthopyroxene grains with no visible exsolutions and large enough for accurate microprobe analysis were selected. A similar geothermometer could not be applied to the garnets in the felsic-pt, although these garnets likely originated by a similar process. In this case, the metamorphic conditions of mylonitization have been estimated from the local paragenesis $\left(500-570^{\circ} \mathrm{C}\right.$ and 0.4-0.6 GPa; for further details, see PitTARELLO et alii, 2012) and, as the ductile deformation has overprinted the pseudotachylyte, it was assumed that the pseudotachylyte must have formed earlier than the mylonitization.

\section{CONCLUSIONS}

In the Premosello area, pseudotachylytes have been found in metagabbro and felsic mylonites from the Ivrea Zone. Previous studies on these rocks have proposed that pseudotachylytes formed coevally with associated ultramylonites under amphibolite facies metamorphic conditions. In pseudotachylytes from both host rock types, garnet has crystallized along the melt vein margins and presents the following characteristics: (i) amoeboid shape, (ii) occurrence of core-and-rim structures with inclusion-free core, (iii) abundant mineral inclusions especially at the core/rim interface, and (iv), composi- tional differences, such as a lower $\mathrm{Mg} / \mathrm{Fe}$ ratio, with respect to the garnet in the host rock. These garnet grains exhibit microstructural and chemical features that suggest fast crystallization from the pseudotachylyte melt, such as: (i) inclusion-rich, epitactic garnet overgrowths on preserved garnet clasts, and (ii), characteristic compositional differences between the preserved garnet core domains and the newly formed garnet overgrowths. Preferred garnet crystallization along the pseudotachylyte margins is referred to a temperature gradient across the vein, with margins that are at lower temperature than the central portion of the vein during the cooling of the melt. Therefore, the preservation of garnet clasts along the vein margin, originally derived from the host rock garnet, is likely favoured by local temperature of the melt below garnet melting point. The garnet clasts that survived melting possibly served as sites for heterogeneous nucleation for new grain formation and for the garnet overgrowth. The garnet growth likely occurred under local equilibrium conditions during the fast cooling of the melt down to the ambient temperature, which corresponded to amphibolite metamorphic facies. This legitimates the use of geothermometry on the new garnet for constraining the ambient conditions immediately after the frictional melt formation in the investigated samples, therefore constraining the formation condition of the pseudotachylytes in the investigated rocks from the Ivrea Zone.

\section{ACKNOWLEDGMENTS}

We wish to thank G. Pennacchioni for the initial inspiration to this project and his continuous support and M. Voorn for assistance with the 3-D reconstruction. This study was supported by the Austrian Science fund (FWF): I471-N19 as part of the international DFG-FWF research group FOR 741-DACH. S. Sinigoi and A. Langone are thanked for the constructive reviews. M. Mazzucchelli is thanked for the editorial handling.

\section{REFERENCES}

Altenberger U., Prosser G., Ruggiero M. \& Günter C. (2011) Microstructure and petrology of a Calabrian garnet-bearing pseudotachylyte - a link to lower-crustal seismicity. Geol. Soc. London Spec. Publ., 359, 153-168.

Altenberger U., Prosser G., Grande A., Günter C. \& Langone A. (2013) - A seismogenic zone in the deep crust indicated by pseudotachylytes and ultramylonites in granulite-facies rocks of Calabria. Contrib. Mineral. Petrol., 166, 975-994.

Austrheim H., Erambert M. \& Boundy T.M. (1996) - Garnets recording deep crustal earthquakes. Earth Planet. Sc. Lett., 139, 223-238.

Boriani A., Burlini L. \& SACCHI R. (1990) - The Cossato-MergozzoBrissago Line and the Pogallo Line (Southern Alps, Northern Italy) and their relationships with the late-Hercynian magmatic and metamorphic events. Tectonophysics, 182, 91-102.

BREARlEy A.J. \& CHAMPNESS P.E. (1986) - Magnetite exsolution in almandine garnet. Mineral. Mag., 50, 621-633.

BRodie K.H. \& RUTTER E.H. (1985) - On the relationship between deformation and metamorphism with special reference to the behaviour of basic rock. In: Thompson A.B. \& Rubie D.C. (eds.), Metamorphic reactions: Kinematics, Texture and Deformation. Adv. Phys. Geoch., 4. Springer, Berlin, 138-179.

CAddick M.J., KonopaseK J. \& Thompson A.B. (2010) - Preservation of garnet growth zoning and the duration of prograde metamorphism. J. Petrol., 51, 2327-2347.

CAMACHO A., VERNON R.H. \& FitzGERALD J.D. (1995) - Large volumes of anhydrous pseudotachylyte in the Woodroffe Thrust, eastern Musgrave Ranges, Australia. J. Struct. Geol., 17, 371-383.

CARLSON W.D. (2006) - Rates of Fe, Mg, Mn, and Ca diffusion in garnet. Am. Mineral., 91, 1-11. 
Demarchi G., Quick J.E., Sinigoi S. \& Mayer A. (1998) - Pressure gradient and original orientation of a lower-crustal intrusion in the Ivrea-Verbano Zone, Northern Italy. The Journal of Geology, 106, 609-622.

Di ToRo G. \& PENnAcChioni G. (2004) - Superheated friction-induced melts in zoned pseudotachylytes within the Adamello tonalites (Italian Southern Alps). J. Struct. Geol., 26, 1783-1801.

Ewing T.A., HERMANn J. \& RuBATTO D. (2013) - The robustness of the Zr-in-rutile and Ti-in-zircon thermometers during high-temperature metamorphism (Ivrea-Verbano Zone, northern Italy). Contrib. Mineral. Petrol., 165, 757-779.

Gaidies F., De Capitani C., Abart R. \& Schuster R. (2008) Prograde garnet growth along complex P-T-t paths: results from numerical experiments on polyphase garnet from the Wölz Complex (Austroalpine basement). Contrib. Mineral. Petrol., 155, 673-688.

GANGULY J. \& SAXENA S.K. (1984) - Mixing properties of aluminosilicate garnets: constraints from natural and experimental data, and applications to geothermo-barometry. Am. Mineral., 69, 88-97.

HANDY M.R. (1987) - The structure, age and kinematics of the Pogallo fault line, Southern Alps, northwestern Italy. Eclogae Geol. Helv., 80, 593-632.

Handy M.R., Franz L., Heller F. Janott B. \& Zurbriggen R. (1999) - Multistage accretion and exhumation of continental crust (Ivrea crustal section, Italy and Switzerland). Tectonics, 18, 1154-1177.

HobBs B.E., OrD A. \& Teyssier C. (1986) - Earthquakes in the ductile regime? Pure Appl. Geophys., 124, 309-336.

KenKMANN T. \& DRESEN G. (2002) - Dislocation microstructure and phase distribution in a lower crustal shear zone - an example from the Ivrea Zone, Italy. Int. J. Earth Sc., 91, 445-458.

KLÖtZli U.S., Sinigoi S., Quick J.E., Demarchi G., TASSINARI C.C.G., SATO K. \& GÜNES Z. (2014) - Duration of igneous activity in the Sesia Magmatic System and implication for high-temperature metamorphism in the Ivrea-Verbano deep crust. Lithos, 206-207, 19-33.

Lund M.G. \& AustRHeIM H. (2003) - High-pressure metamorphism and deep-crustal seismicity: Evidence from contemporaneous formation of pseudotachylytes and eclogite facies coronas. Tectonophysics, 372, $59-83$.

MAgLOUGHLIN J.F. (1992) - Microstructural and chemical changes associated with cataclasis and frictional melting at shallow crustal levels: the cataclasite-pseudotachylyte connection. Tectonophysics, 204, 243-260.

Moecher D.P. \& Steltenpohl M.G. (2009) - Direct calculation of rupture depth for an exhumed paleoseismogenic fault from mylonitic pseudotachylyte. Geology, 37, 999-1002.
Nielsen S., Di Toro G., Hirose T. \& Shimamoto T. (2008) - Frictional melt and seismic slip. J. Geophys. Res., 113, B01308. doi 10.1029/2007JB005122.

PASSCHIER C.W. (1982) - Pseudotachylyte and the development of ultramylonite bands in the Saint Barthélemy Massif, French Pyrenees. J. Struct. Geol., 4, 69-79.

Pennacchioni G. \& Cesare B. (1997) - Ductile-brittle transition in the pre-Alpine amphibolite facies mylonites during evolution from water-present to water-deficient conditions (Mont Mary nappe, Italian Western Alps). J. Struct. Geol., 15, 777-791.

Pittarello L., Pennacchioni G. \& Di Toro G. (2012) - Amphibolitefacies pseudotachylytes in Premosello metagabbro and felsic mylonites (Ivrea Zone, Italy). Tectonophysics, 580, 43-57.

RÅHEIM A. \& GREEN D.H. (1974) - Experimental determination of the temperature and pressure dependence of the Fe-Mg partition coefficient for coexisting garnet and clinopyroxene. Contrib. Mineral. Petr., 48, 179-203.

SIBSON R.H. (1975) - Generation of pseudotachylyte by ancient seismic faulting. Geophys. J. Roy. Astr. Soc., 43, 775-794.

Sinigor S., Quick J.E., Demarchi G. \& KlötZli U. (2011) - The role of crustal fertility in the generation of large silicic magmatic systems triggered by intrusion of mantle magma in the deep crust. Contrib. Mineral. Petrol., 162, 691-707.

SPEAR F.S. (1993) - Metamorphic Phase Equilibria and PressureTemperature-Time Paths. Mineralogical Society of America, Washington D.C. 799 pp.

VAVRa G., Schmid R. \& Gebauer D. (1999) - Internal morphology, habit and $\mathrm{U}-\mathrm{Th}-\mathrm{Pb}$ microanalysis of amphibolite to granulite facies zircons: geochronology of the Ivrea Zone (Southern Alps). Contrib. Mineral. Petrol., 134, 380-404.

White J.C. (2012) - Paradoxical pseudotachylyte. Fault melt outside the seismogenic zone. J. Struct. Geol., 38, 11-20.

WisNIEWSKI W., VÖLKSCH G. \& RÜSSEL C. (2011) - The degradation of EBSD-patterns as a tool to investigate surface crystallized glasses and to identify glassy surface layers. Ultramicroscopy, 111, 1712-1719.

WhitNEY D.L. \& Evans B.W. (2010) - Abbreviations for names of rock-forming minerals. American Mineralogist, 95, 185-187.

WolfF R., Dunkl I., Kiesselbach G., Wemmer K. \& Siegesmund S. (2012) - Thermochronological constraints on the multiphase exhumation history of the Ivrea-Verbano Zone of the Southern Alps. Tectonophysics, 579, 104-117.

ZingG A., Handy M.R., Hunziker J.C. \& Schmid S.M. (1990) Tectonometamorphic history of the Ivrea Zone and its relationship to the crustal evolution of the Southern Alps. Tectonophysics, 182, 169-192. 